\title{
The genesis of violent careers
}

\author{
- Ferdinand Sutterlüty \\ Institut für Sozialforschung, Frankfurt am Main, Germany \\ Translated by Adam Blauhut
}

\begin{abstract}
A B S T R A C T - This article discusses the concept of a violent career and demonstrates its explicative value for biographical research and the sociology of crime. Relying on a study grounded in intensive interviews with young repeat offenders, it distinguishes between trajectories of violence and disrespect suffered in the family on the one hand and violent action schemes on the other. After reconstructing the first phase of violent careers - characterized by victimization within the family and presaging a violent reacquisition of power and recognition - the article identifies biographical turning points and explains them using the concept of epiphanic experiences. These turning points bring about an identitypromoting switch in roles from victim to perpetrator. Finally, three essential aspects of violent action schemes are discussed that are characteristic of the second phase of violent careers: interpretive regimes, which can shed light on the long unanswered question of how violent relations in families are transferred to young people's social environments; intrinsic motives for violence, which arise from exhilarating experiences of the use of physical force; and mythologies of violence that enable young people to glorify violent behavior and its effects.
\end{abstract}

K E Y W O R D S E violence, child abuse, family interaction, recognition theory, trajectory, action scheme 
Violent offenders mainly figure in sociological research as individuals who plan and act rationally: they wish to gain power over others, seize material possessions by means of force, protest against discrimination and exclusion, come to grips with deprivations, earn the recognition of their opponents, honor their value commitments, or simply show who they are. Whether they are safeguarding their interests, complying with their normative orientations or expressing their identity, they act deliberately, and their actions are oriented to the future - this is the way they are usually portrayed in sociological research on violence. They pursue behavioral goals and in doing so exercise a degree of control over themselves and their environment. At first glance, talk of violent careers appears to build on this image of an individual who acts methodically. However, as this article intends to show using young repeat offenders as an example, the biographical developments that can be described with this concept have an additional dimension, one that is determined by adversity, strokes of fate and experiences of suffering. This thesis emerged from a study I have conducted, one that supplies the underpinnings for the following conceptual reflections (Sutterlüty, 2002).

This study, carried out between 1996 and 2000, used the method of grounded theory (Glaser and Strauss, 1967; Strauss and Corbin, 1990) and was based on two qualitative interviews ${ }^{1}$ with 18 Berlin youths aged 15 to 21. The sample comprised 15 young men and three young women of different ethnic backgrounds and group affiliations. ${ }^{2}$ With the exception of three participants, who were included for comparative purposes, all the youths had repeatedly committed serious violent crimes. The following sections outline a developmental pattern that is typical for violent careers.

\section{On the concept of violent careers}

Several decades ago, Edwin M. Lemert (1967) criticized talk of 'deviant careers', arguing that the term was too closely linked to role models from the professional world and that it wrongly suggested that deviant persons went through specific stages in a particular sequence. Indeed, the developmental stages through which young violent criminals pass cannot be grasped using a 'career' concept that presumes set opportunities and structures within which they methodically and strategically move forward. Although their violent careers are characterized by phases of goal-oriented action, the young people also go through phases in which they feel they are 'buffeted about' by circumstances and lose control over their lives. At the same time, biographical ruptures play an important role in their life stories. If it is to be applied to the formation and progression patterns of youth violence, the career concept must take into account discontinuities and 
contingencies as well as the individuals' temporary inability to control the course of their lives. This is how 'addictive careers' - to name just one example - entered into the language of both quotidian and scholarly discourse. This type of process, shaped by conscious decisions, compulsive behavior and tragic suffering is more closely related to the concept of a violent career than it is to the traditional concept of a professional career that follows an institutionally defined structural and behavioral pattern.

David Matza's (1964) analysis of youth delinquency introduced to the sociology of crime the figure of the 'drifter', an individual who, in a process that begins unnoticed, successively slips into a subculture of delinquency. The drifter gradually adopts a lifestyle that oscillates between the loss of control over his life and attempts to regain control. In describing these young delinquents, Matza speaks of a 'mood of fatalism' that is tinged by their perception of themselves as the victims of external forces and not as human beings who are capable of actively influencing their environments. Matza's enduring service to the sociology of crime and sociological action theory lies not only in the fact that he called attention to an element of passive drifting and deliberate yet derailed efforts to control action by these individuals. He also showed that drifters commit crimes to combat their sense of fatalism and to recreate a 'mood of humanism'. In this way, they can perceive themselves as instigators, that is, as individuals who are acting to make things happen and can demonstrate their self-efficacy. The loss and recovery of the capacity to act are also predominant themes in the biographies of young offenders.

What Matza describes as a constant oscillation between two poles, between effective action and a loss of control, applies to the violent careers of young people insofar as their careers unfold between the same two poles. However, these careers do not progress in alternating shifts between these two extremes. Rather, they consist of two clearly delineated phases: the first, which sets in at an early age and is ignored by Matza, is a period in which the youths suffer violence and disrespect within the family, and in which their experiences of powerlessness and humiliation are determinant factors. This is followed some time later by a phase in which they themselves use violence and which focuses on the recovery of the capacity to act and the acquirement of recognition. To quote Fritz Schütze, in violent careers, a 'trajectory of family violence and disrespect' is supplanted by an 'action pattern' (Handlungschema) that involves the use of violence, even though, as we shall see, each phase contains specific elements of the other. Further, Norman K. Denzin's concept of epiphany can be employed to more accurately define which experiences typically bring about the shift from the role of victim to that of perpetrator, the segue from the trajectory of suffering into the pattern of violent action. The three elements mentioned above - the trajectory of family abuse and disrespect, the epiphanic experience of 
a role reversal, and the pattern of violent action - are constitutive of the concept of violent careers.

These three elements of violent careers do not imply a teleologically oriented development in which one stage follows the other in a prescribed manner. Yet they do call attention to the fact that the violent acts of young repeat offenders are interconnected and integrated into a recognizable developmental process as opposed to being isolated events. This type of developmental process, ascertained ex post, is not dominated by causal necessity. Rather, violent careers depend on contingent events and consequences of action, which function as direction-setters and social barriers in an individual's life. In this sense, a violent career is a path-dependent biographical development.

Fritz Schütze (1995) criticized both the sociological mainstream and interpretive sociology for their focus on individuals who are rational and capable of action, who cognitively structure their surroundings through order-creating interpretive work, and who actively appropriate these surroundings in their lives. As regards the phenomenological tradition of Alfred Schütz, this criticism of interpretive sociology may be justified, but it must be relativized in the case of the Chicago School of Sociology and Symbolic Interactionism. After all, the trajectory of suffering that Schütze introduces as a counter-concept to that of action patterns stems from this tradition (Strauss and Glaser, 1970). ${ }^{3}$ Whereas the concept of action patterns is based on the model of a rationally planning and acting individual (Sutterlüty, 2004), the trajectory concept describes biographical and interactive processes that are marked by painful experiences of suffering. Individuals who are caught up in this trajectory are unable to cope with specific events in their lives and lose their capacity to act. They are swept along by the current instead of exerting control, and they react more than they act. Trajectories have destructive effects on identity-building processes and alienate individuals from previous self-images. The first phase in the violent careers of young people - which is dominated by family violence and disrespect - represents this type of trajectory of suffering.

\section{Experiences of family violence and disrespect}

As the interviews in my study show, the young people who became repeat offenders were, almost without exception, victims of violence for longer periods of time in the early phases of family socialization (see Alfaro, 1981; Pfeiffer and Wetzels, 1999). ${ }^{4}$ For these youths, childhood can be described as a trajectory of violence whose characteristic feature is powerlessness. Insofar as there was no person of importance in their lives who could offer effective protection or represent their rights, abuse in the family, according 
to the interviewees, went hand in hand with the feeling of being physically threatened and defenseless. A similar process can be observed among youths who were forced to witness their mothers being battered by their fathers, or a sibling being beaten by one of their parents. They, too, said that they regarded themselves as helpless witnesses who were condemned to powerlessness (see also Jaffe et al., 1990; Osofsky, 1995). 'I couldn't do anything, I was just a child', is the phrase that several interviewees used, in nearly identical fashion, to describe the experience of being physically abused and of witnessing family violence. ${ }^{5}$

If children are direct victims of physical violence, an experience of powerlessness results from their physical defenselessness. The victimized children learn that they are at the mercy of their parents' or their siblings' blows. Often this experience is intensified by the unpredictability of the abuser, who is often an alcoholic, or by the limited control that they had over the recurring violence, which they could do little to prevent. For instance, Kilian, a 21-year-old skinhead, recounted how, as a child, he was beaten again and again by his mother for incidents that were beyond his control - for coming home with dirty clothes, for a broken toy, for not immediately understanding his homework, and so on. In response to the hopelessness caused by these situations, the children develop adaptive strategies: in many cases they adopt the perspective of the abuser and conclude, with their childlike logic, that they are beaten because they deserve punishment. This can be seen in the case of Murat, a 16-year-old of Polish descent who recalled situations in which his stepfather beat him for no reason at all: 'Yes, it was strange, he just hit me. And sometimes I thought there was a reason for it, or he hit me because I deserved it.'

In the case of indirect victimization caused by observing scenes of family violence, the experience of physical defenselessness results from the children's inability to protect an important figure from the violence of a more powerful abuser. The children are made into powerless witnesses and forced to view violent acts without the power to act. When the youths describe situations in which their fathers battered their mothers or one parent beat one of their siblings, they often narrate the story as if they themselves were the ones being hit. This experience of powerlessness involves a moral injury, particularly when children are forced to witness violence within the family. It stems from the perception that, due to their physical inferiority, they cannot act as they deem fit. They are unable to behave in the way they believe is appropriate - that is, they cannot help the person they love and undo the injustice. Since they are constantly kept from carrying out the action they intuitively feel to be correct, they not only regard themselves as powerless in a physical sense, but they also feel undermined as moral beings. This has destructive consequences for the way they relate to themselves. Murat provides an example of this when he describes 
his response to his stepfather's violent treatment of his mother: 'I always saw it, and I always thought that if I was older, I would hit him right off, but I couldn't do anything because I was too small. And sometimes I hated myself for not doing anything and for him hitting my mother.'

This remark not only reveals the deep self-hatred that can result from witnessing family violence without the power to act. It also calls attention to the fact that the thoughts of children who have no power to end family violence are quickened by the fantasy of striking back. Such projections of counter-violence are characteristic of children who are directly and indirectly victimized by violence. For instance, when describing afternoons on which his mother 'slapped both cheeks' because he was unable to do his homework - afternoons that became seared in his memory - Kilian comments: 'And then I hated my mother for a time. Once I even wanted to poison her. But I didn't know what to use, ha ha.' A careful examination of the young people's stories shows that these violent fantasies crop up at an age when children have no way to defend themselves against their hopelessly superior abusers. These fantasies stem from their desire to one day overcome the aggressor and despot within their families, to violently call him to account as soon as they have the requisite physical strength. In cases like these, childlike fantasies of counter-violence help forge a selfimage that is borne by the idea of becoming a perpetrator in the future.

Among children, trajectories of ongoing family violence are always associated with states of fear that are sustained by the expectation that they will once again be beaten or forced to witness the physical abuse of another family member. The fear of violence causes their sense of powerlessness to permeate situations where violence is not used directly. This becomes evident in Murat's memories of the nights in his childhood when he was unable to sleep because he found himself 'waiting' for his stepfather to return, wondering 'whether he's going to act up when he does, whether he's going to beat my mother'. Children like Murat internalize their powerless position within the context of family violence. It occupies a great deal of their thoughts, and at some point the experience of powerlessness turns into fantasies of counter-violence. This is a consequence of family abuse observable throughout the sample, and it adds the characteristics of an action pattern to the trajectory of victimization. The 'trajectory projection' (Strauss, 1993: 55) - that is, the vision of continued violent interaction within the family - is shaped by the idea of violently seizing power.

Young people who repeatedly commit violent crimes have usually not only been victims of violence, but also targets of massive disrespect within their families. Whereas a sense of powerlessness may result from experiencing physical vulnerability in violent situations, disrespect represents a nonviolent violation of the need for, and the claim to, recognition. ${ }^{6}$ Experiences of powerlessness and disrespect can empirically mesh, as is vividly 
captured in the phrase 'pain of the soul' which Bebek, a 16-year-old Kurdish girl, uses to describe the wounds inflicted by the brutal, humiliating blows of her elder brother. Even so, one must conceptually differentiate between these two types of experiences, which are attributable to various types of interaction and characterized by a different physical proximity: experiences of powerlessness are directly related to the body insofar as the individuals in question, if they do indeed become victims of violence, have an immediate physical experience of their inability to act. Or, if they are forced to witness violence, these individuals are confronted with the fact that they are incapable of a physical response that suits their affective and moral impulses. Experiences of disrespect are based on family interactions that non-violently violate the children's need for recognition and claim to attention, respect and appreciation. In this sense, experiences of disrespect can damage the trust that young people place in themselves and the world, which has bearing not only on their physical, but also on their emotional and social integrity (see Honneth, 1996; Todorov, 2001).

From the interviewees' narratives, we see that experiences of disrespect emerge from a variety of interactions that have often hardened into entrenched forms in family life and impacted decisively on the youths' socialization. They range from the privileging of siblings to intra-family marginalization, from negative classifications to true humiliation rituals, from parental neglect to a fundamental rejection by other family members. As such, experiences of disrespect can be rooted in active humiliation, that is, in actions by other family members that aim to humiliate the children and injure their feelings of self-worth; or they can result from a passive refusal to grant recognition, including not only a failure by other family members to acknowledge and support a child, but also neglect or a lack of attention, which need not be deliberate to be perceived as extremely degrading by the children. In most cases, a dynamic of disrespect inheres from the start in the family socialization of young people with violent careers.

Two slightly different examples can illustrate this point. The biography of 21-year-old Xaver, who was active in the skinhead scene for a time, is peppered with experiences of active humiliation by his mother. At a very early age, his mother let him know that she 'didn't want [him] anymore'. According to Xaver, she missed no opportunity to belittle him - for instance, by making him and his sister feel that they were only a burden or demanding of both schoolchildren that they pay for food and clean clothes. When Xaver began having trouble at school, his mother called him the 'black sheep of the family'. He was condemned to play this role ever afterward, and when, at age 13, he painted a swastika on a school wall, his mother responded by sending him to a children's home - or 'shunting him off', as Xaver perceived it. In response to Xaver's other misadventures and crimes, which in fact seem to be paradoxical attempts to gain the acceptance of 
others (Winnicott, 1956), she engaged in additional name-calling, predicting he would become a 'drinker' and 'convict' like his father and finally abandoning him altogether.

Like Xaver, 15-year-old Fabian, who participated in the violent rampages of German and Arab gangs, experienced disrespect and humiliation throughout his life. However, in his family socialization, active shows of disrespect were less dominant than a passive refusal to grant recognition. Fabian's aggressive father, who worked as a long-distance trucker, was often absent during his childhood, and he had to cope with his constantly drunk mother. What he perceived as particularly 'bad' at the time was his mother's inaccessibility. When he wanted to tell her something, she would at best give a laugh. With this failed communication, his most legitimate claims on her as a child were rebuffed. When he started school, a love affair blossomed between his father and his half-sister, who was 10 years older than him and had been raised by his maternal grandparents. After a tumultuous period in the family's life, Fabian's father separated from his mother, and his 18-year-old half-sister took her place in the home. Yet, as he recalled, she was never able to show the 'right love' for him and his three brothers. She never really understood them and never had the 'proper attitude' for a mother. These remarks betray the injuries Fabian suffered in this special family constellation, ones that continued to torment him at the time the interview was conducted.

Both types of disrespect mentioned above produce negative self-images. At a very early age, the children's identities are destabilized, and their selfimage is shaped by humiliation in the family. Children whose worth is constantly being questioned within their families are given the impression that they do not deserve the affection and kindness of others and that the contempt with which they are treated is justified. As a result of the degradation and disdain, they lose trust in their own abilities and their own value. Highly significant are the negative labels used by parents or other family members, which assign the children the future roles of ne'er-do-wells, failures and criminals. Such classifications become integrated into their selfimage. For instance, Xaver was never able to shake off his 'convict' image and was in fact imprisoned twice for a total of three years for committing several violent crimes, burglaries and muggings. The 'decent kid' he had always wanted to become in defiance of all his mother's predictions was now just a 'criminal' who, according to Xaver, had to 'come to terms with pouring several years of [his] life down the drain'. The biographical narratives of the other young people also contain this fatalism, which lends the belittling labels the character of self-fulfilling prophecies. Since they loathe themselves, the youths comport themselves in a way that ultimately causes others to reject them - not only their parents and siblings, but also their peers and teachers (a finding confirmed by Engfer, 1986). In accordance 
with labeling theory (Becker, 1963), children who are treated with disrespect are unable to rid themselves of these negative labels well into their adolescence. They inherit a specific problem: that of intersubjective recognition and - the reverse side of the coin - intrasubjective self-respect. Trajectories of disrespect and the resulting negative self-images play just as important a role in the subsequent use of violence in adolescence and young adulthood as do both the trajectories of powerlessness in violent family contexts and the fantasies of counter-violence resulting from them. In the process, a characteristic pattern governs how these trajectories of suffering are transformed into patterns of violent action.

\section{Epiphanic experiences and biographical turning points}

The young people who were interviewed attributed to certain violent acts which they themselves had committed a lasting significance for their development. This phenomenon can be analyzed using the concept of epiphanic experiences which Norman K. Denzin (1989) introduced into biographical research in the field of sociology. Epiphanies, as Denzin uses the word, describe revelatory moments in a person's life that show his or her character in a new light in unique, often critical situations. The experience that people have in such situations leaves an indelible mark on their lives. Since they are the source of transformational potential, Denzin links epiphanic experiences with the concept of turning points that originally goes back to Everett C. Hughes (1971). After an epiphanic experience, or so the concept implies, a person is irrevocably changed. In subjective terms, he goes through a status passage and relates to himself in an entirely new way.

Young repeat offenders talk in surprisingly similar ways about violent acts that give their lives a new direction. They characterize these acts as events that form the prelude to a new perception of themselves. These epiphanic experiences of violence often crop up in descriptions of situations in which the youths cast off the role of victim and strike back at the physical abuser in their families. In most cases, this occurs when they are threatened with a beating or humiliation and raise their hand against their mother or father for the first time, overpowering the person who had hitherto beaten them. Long-harbored fantasies of violence provoked within the family are realized in this role reversal. It is often a kind of 'coming out' as a violent offender and accompanied by a new definition of the self, which is based on two key ingredients: their ability to defend themselves and their willingness to use violence. The stories of biographical incidents to which the youths attribute threshold experiences of an epiphanic nature have a very specific structure: the corresponding acts of violence create a clear division 
between 'before' and 'after' - as if they had a distinct life before and after the narrated event. The young offenders are able to view this event as a structuring element in their biographies because, in the epiphanic experience of a role reversal, they are suddenly given an opportunity to end their role as victims.

Kilian describes how his mother often 'put him down' with the words: 'You'll never get anywhere or achieve anything!' He finally tells her his opinion, letting his fists 'do the talking'. In Killian's eyes, the fact that he 'punches her' just when she is about to hit him indicates a fundamental reorientation. His pithy comment that, through this act, he 'finally stood up' to his mother emphasizes the reversal of the previous relationship - as does his remark that 'she's been afraid of me ever since'. Wearing his Springer boots, Kilian leaves his mother's home, only to return with his skinhead friends to complete the job he had just started. As he relates it, he 'took' the apartment with his mates, 'beat' his wailing mother and later 'threw her out'. The entire situation is orchestrated as if he wants to make a deliberate show of the role reversal, present his 'authentic' self to the public and finalize this biographical turning point. By attacking his mother, Kilian does indeed bring about a final break with her, and from that point on he devotes himself wholly to his 'substitute family', as he puts it - to the radical right-wing skinhead scene.

An incident described by another skinhead, 19-year-old Kai, also serves as a biographical turning point. Kai was beaten for trivial reasons by his father, and at the age of 12 or 13, after his father, in a drunken state, attacked him with a knife, Kai took hold of the weapon with the intention to stab him. Up to that point, Kai, who in his own words was 'raised on violence', had 'put up with' his father's beatings. Afterward he 'struck back'. The 'awesome feeling' that Kai associates with the violent disempowerment of his father was a frequent theme when, in the interview, he discussed his violent acts outside the family. Murat also tells of a similarly dramatic situation in which his stepfather once again beat his mother, and Murat wanted to attack him with a knife for which he had saved for a long time 'to protect' himself from the man. However, he was held back by his older brother. The true role reversal comes later, when he is 14: in response to blows he himself suffers, Murat overpowers his stepfather with his brother and strikes back at him. The family then separates from the hated man.

Yet this type of role reversal is not limited to acts of counter-violence against the abuser within the family. It can also occur in entirely different contexts. Not only does the youths' family history of victimization provide them with a 'key' for interpreting situations in which they respond violently to threats by others outside the family. It also transforms these violent acts into epiphanic experiences of a role reversal. Regardless of whether the youths have this experience in or outside the family, it falls under the 
category of a cumulative epiphany (Denzin, 1989). In distinction to a major epiphany, ${ }^{7}$ which results from a singular unannounced event and forms a turning point par excellence in an individual biography, a cumulative epiphany emerges from events in which a long previous history of violence gradually assumes critical mass. This is the case when the youths' new behavior in the role of perpetrator is a consequence of the experiences that they have had for years as victims and that enable them to perceive the role reversal as an epiphany in the first place - as a liberating act that turns the trajectory of suffering into a pattern of violent action.

When young people construct their biographical narratives around special experiences of violence and interpret these as turning points in their lives, they confirm the sociological concept known as the Thomas Theorem: 'If men define situations as real, they are real in their consequences' (Thomas and Thomas, 1928: 572; see also Merton, 1949: 179 ff.). In addition, they demonstrate that life stories characterized by violent careers represent 'interpretive patterns' in the truest sense of the word (see Alheit and Dausien, 1992). Biographical narratives like those told by the interviewees not only comprise a sequence of events, but also have a deep structure that is apparently firmly rooted in western culture. In Christianity and other religions, an individual's efforts to understand his life in relation to a single event or a decisive turning point have a long tradition. A biblical model for this structure can be found in the figure of Saul, who sees a bright light from heaven, falls off his horse and experiences his true calling as an apostle. He is then transformed into a wholly new person with a new name - Paul (Acts 9). This type of biographical interpretative pattern can be found in a large number of conversion and awakening stories, and its outlines can also be seen in the young interviewees' descriptions of their violent careers. Just as Paul's transformation from a persecutor of Christians to a preacher of the Gospel is always manifest in his deeds, so too is the young peoples' rebirth as violent offenders always manifest in theirs: they continue to have 'minor epiphanies' of violence ${ }^{8}$ long after their first key role reversal is concluded. The biographical interpretative pattern continues to be confirmed and consolidated in individual acts.

The epiphanic or revelatory character of certain acts of violence can largely be explained by the fact that the young people regain the ability to act that they have lost within the context of family violence. Of course, the consequences of a trajectory of suffering are not eliminated through a single violent act. They continue to have an impact: the young people want to go on demonstrating their capacity to act, which is intended to end their previous history of physical abuse and denied recognition, or even to allow them to forget it. The particular patterns of violent action thereby established are controlled by an 'interpretive regime', in which the long-term effects of family trajectories of powerlessness and disrespect are manifested. 


\section{Interpretive regimes with an affinity for violence}

Interpretive regimes that bring forth violence are perceptual patterns acquired in family socialization. They render the youths particularly vulnerable in situations that evoke their early experiences of powerlessness and disrespect. The youths are quick to make out, in the behavior of their interaction partners, an intention to humiliate or attack them. This perception determines the way they define a situation that leads to violence. Often all that is required to cause this perception is a glance that they interpret as being contemptuous or aggressive; a single false word suffices to trigger their violent 'defense'. Here we see an internal connection to their experience of victimization within the family, one that can be traced into the subtle twists and turns of their narratives. In the practice of violence, dichotomous interpretations are at work that, like the complementary negative experiences within the family, circle around the semantics of power and powerlessness, of recognition and disrespect.

We are justified in speaking of interpretive regimes in this case because the perception of an interactive situation that leads to violence is an interpretation - just as every action is based on an interpretive definition of the given situation, and just as individuals always act based on the meaning that objects possess for them (Blumer, 1969). These interpretations can be characterized as interpretive regimes because they do not spring from the youths' conscious decision to process interactive situations in any particular way. Rather, the young people interpret the situations in light of paradigmatic events in the past without being able to explain this to themselves or to others. They are under the sway of their experiences as victims; they are subject to the regime. For biographical reasons, the corresponding situations are overdetermined - not only in terms of the way they are interpreted, but also in terms of the way they are responded to. Interpretive regimes in this sense have an affinity for violence because the young people view situations through the lens of interpretative patterns that make a violent response seem the most logical. They do not want to remain the victims of violence and humiliation, and since they project their family's hostile world onto other behavioral contexts, they believe they must constantly defend themselves in order to preempt attacks by others. Finally, these interpretations have an affinity for violence because they need not always lead to its use. Even if they provide an impetus for violent action, there is no automatic mechanism. At issue are proclivities for action whose fulfillment depends on the most diverse situational conditions and on existing opportunity structures.

An incident from the interview with Bebek, a 16-year-old Kurdish girl born in Berlin, shows how interpretative regimes with an affinity for violence work. It begins when she tries to enter a room in her youth club 
to talk to a few friends who are dancing. At the door, there is a verbal exchange between Bebek and an Iranian girl of her own age who does not want to let her in, as the dance exercise is already underway. The girl first claims to have this authority herself, then refers to instructions from the social worker. After a short argument, Bebek hits her opponent so hard that the girl is taken to the hospital with a skull trauma and broken ribs; Bebek will later have to answer in court for her actions. The escalating tension between Bebek and the girl draws its force from the theme of exclusion. Bebek, who at the start of the narrative emphasizes that she had previously gone to the youth center 'almost every day' and enjoys 'privileged status' there, sees her membership challenged by her opponent. If one recalls Bebek's experience as a victim, it becomes clear that there are antecedents to this conflict in the family, where Bebek always had the role of outcast and was forced to knuckle under to the male family members' violent patriarchal regime.

The theme of exclusion has a powerful presence in the passage in which Bebek describes how her family used to try to convince her she was a foundling whom her parents had discovered in a 'garbage can'. Despite her tears, the family members would confirm this story, pointing to her 'white skin' as proof, which differed from their own brown complexion. The theme of skin color is also present in the interview when Bebek, in response to a question by the interviewer, briefly describes her Iranian opponent in the youth center, saying: 'She has brown skin herself.' It is indeed striking that this detail should recur in an incident that centers on exclusion - it was, after all, the dark skin color of her family members that provided a clear sign of affiliation with the family. Prior to Bebek's violent outburst, one question becomes increasingly important in the dialogue between the two girls: whether Bebek's opponent is entitled to determine who is allowed in. Before striking her opponent, Bebek exclaims, 'You don't have any say here!' another telling statement, since Bebek herself was forbidden to speak in the family, and this ban plays a central role in her descriptions of its interactive structures. For instance, when she wanted to voice her opinion at the table, Bebek was either not listened to or silenced by her father or older brother, who said: 'You're too small, shut up!' Whereas in her family any protests she dares to make remain ineffectual, her newly acquired ability to defend herself breaks new ground in her violent response. The semantic horizons are the same in both cases: what is at stake are special forms of exclusion and affiliation. The interpretive pattern to which Bebek is subject, which overshadows and shapes the situation in the youth center, has been in place for quite some time. She perceives her opponent's behavior in light of old problems whose semantic traces are clearly visible in the interview: the problem of intra-family marginalization, of her treatment as a stranger on her home turf, and of her constant sense of subjugation. 
Another factor determines Bebek's violent behavior, namely, her female identity. In this case, too, the semantic subtleties of Bebek's descriptions shed light on the evolution, within her family, of her situational definitions. A telling example comes in a story she tells of punching a boy in the face for calling her girlfriend a 'whore' in a subway station. This situation turns on the issue of honor, that is, on her friend's virginity and good reputation. On several occasions, this issue provided grounds for her father and bother to beat or humiliate her. When she entered into friendly relations with boys or talked to a female neighbor of ill sexual repute, she was even forced to submit to a true humiliation ritual: her brother made her lie on the ground before him, and he beat her legs with a stick. ${ }^{9}$ As Bebek's description of the subway incident makes clear, she felt implicated in the label applied to her friend - as if this label were aimed at herself and she were the one who was called upon to defend her identity. Reflecting on the blow she gave the boy, she remarks that, in contrast to other girls, it is not enough for her to know what kind of person she is. She won't put up with being called a 'whore'. She often displayed this defiant attitude of 'not putting up with anything', ${ }^{10}$ which can only be understood as an inversion of her experiences within her family, in situations where an external observer would fail to see any challenge, threat or intended injury on the part of another person.

On the one hand, the concept of interpretive regimes points to a special sensitivity in situations in which experiences that the youths know from their homes threaten to recur. On the other hand, it is linked to their willingness to use violence in such situations. These interpretive regimes make violence a likely option since the young people project the adversity they have experienced in their homes onto other social spheres. As their web of social relations widens, so too does the space in which they again and again 'discover' the aggressive rejection and ignorance that they have known in their families since their childhood. Along with cumulative epiphanies, the concept of violent interpretive regimes is thus able to address the long unanswered question of how violence is transferred from the youths' family life to their life-worlds. ${ }^{11}$ It posits a biographical continuity that permits one not only to speak of 'violent careers', but also to see their beginnings in trajectories of physical abuse and disrespect. Just as the dimension of an action pattern enters into trajectories of family abuse by means of projections of counter-violence, so too is the aspect of a trajectory of suffering brought into patterns of violent action by means of an interpretive regime with an affinity for violence. Unbeknownst to the young people, their history as victims asserts itself precisely in those situations in which they demonstrate their capacity to act and defend themselves. The trajectories of suffering are canceled out in violent action: they are precariously overcome and preserved at the same time. 


\section{Intrinsic motives for violence}

As violent careers progress, motives mostly come into play that can no longer be reduced to the situational definitions and interpretive patterns described above. The violence becomes excessively cruel and takes on a dynamic of its own, one that is not sufficiently accounted for by a 'dispositional' explanation based on the offenders' biographically determined behavioral tendencies. In this case, the explanation for the violence and its motives must be supplemented by 'situational' analysis, which is far less developed in the sociology of crime (Birkbeck and LaFree, 1993). After all, the descriptions in the interviews repeatedly show that the young people associate a direct subjective gain with their violent acts, a gain that consists of an especially intense experience. In one form or another, the youths describe the use of violence as a fascinating experience that not only creates a disinhibitory dynamic, but also becomes a motive for additional violent acts. The violence becomes an end in itself and follows intrinsic motives for violence - that is, motives that emanate from the experience of using violence and do not require any objectives or purposes external to the situation. We can identify three aspects of the violent experience that lead to such intrinsic motives: the triumph of physical superiority, the victim's pain, and the break with the daily routine.

The young perpetrators associate with victorious violence the intoxicating experience of triumph, of being stronger than and having power over others. This can became an independent motive for violence and in extreme cases develop a dynamic of its own, one that leads to a desire to bring others to the brink of death and sit in judgment over their lives. No matter how cruel the violence is in individual cases, perpetrators with such motives are aiming for much more than self-assertion. They desire the physical subjugation of others, they want to see them literally below themselves in order to feel powerful and important. When the youths emphasize that their opponents are below them and they stand above, when they stress their own lack of injury and the others' wounds, when they mention their own freedom to act and the others' inability to move, they demonstrate how closely the feelings of strength and omnipotence are linked to the coordinates of bodily experience. These feelings draw on the direct physical presence of the victim and the sensory evidence of his being broken. When the youths say that violence brings an 'incredible feeling of power' and 'the thrill of victory', they are describing what drives them to their acts and what they see as the source of the intrinsic attraction of violence. In this case, the motive for action is based on what occurs in the perpetrators' relationships to themselves when they use violence. What is at stake is a sense of the self, even if this is based on a specific, extremely asymmetric relationship to 
another person: an exhilarating self-perception that feeds on the irrefutable certainty of one's own grandeur and strength.

This point is illustrated in an incident related by Murat. It begins at Murat's school in West Berlin, when an Arab youth spreads the news that, at his school in East Berlin, he and his black friend were cursed out as 'shitty foreigners' and beaten by a group of skinheads. After emphasizing that the 'Nazis' challenged them to a fight, the youth is ultimately successful in persuading Murat and a few Turkish classmates to avenge the skinheads' crime. The group of 16 , armed with clubs, sets out in search of the skinheads, and after a verbal exchange, a pitched battle ensues during which two Turks in Murat's group draw their knives and stab one of the skinheads several times, causing life-threatening injuries. Murat's description at first appears to leave little doubt as to the purpose of the fight - to call the skinheads to account for their racist words and actions and, beyond this, to take up the challenge to fight. However, as the dynamics of the situation unfold, an additional motive for action surfaces, one which Murat describes as follows: 'We really wanted to beat them to a pulp. We wanted them to grovel on the ground before us, saying: "Stop, please! We're sorry for what we said." We wanted to beat them to a pulp.' According to this description, Murat and his gang wanted to create a situation in which their opponents were completely subjugated and they could gloat over their horror. The violence aims not only at the physical subjugation of the opponent, but also at a verbal concession of his inferiority and the perpetrator's malicious pleasure in his terror: the group wanted the skinheads to tremble with fear and beg for mercy. They were supposed to fall to their knees and confirm the power of Murat and his group in a formal act of submission. Here, the triumphant experience of proving oneself superior by physically subjugating an opponent in a violent undertaking becomes the decisive motive for action.

A comparable web of motives led the skinhead Kai to embark on a nearly routine search for persons to be the target of his violence. When he got up in the morning, Kai explains, he would often have a premonition that 'something would happen' that day. The behavior at which he took offense in his randomly chosen victims merely seems to serve the purpose of identifying them as the objects of his violent intentions. Kai's talk of a 'feeling of power' reveals the driving force behind his attacks, which at first glance seem fully irrational. He has this sense of power when he views his victims beaten and often motionless on the ground before him. One incident after a visit to a disco with a girlfriend and a few male friends provides a gauge of the exact nature of this feeling, which constantly recurs in Kai's stories. When leaving the disco, they meet, as Kai puts it, a 'Yugoslav or a Turk', who makes a 'funny remark'. Kai punches him in the face, kicks him and throws him in front of an approaching streetcar, which is able to brake 
in time. Kai's comment is that his opponent 'unfortunately survived' and afterward ran off. Referring to the incident later on, Kai says: 'And he was almost run over, and I would have committed my first murder. Not that I wanted to. Then I had this feeling of power again.' The ambivalent feelings of regret that Kai expresses over the non-fatal outcome of his violent crime result from his desire to invest himself with godlike powers and ultimately to savor the survivor's triumph over the dead (Canetti, 1962).

The second aspect of intrinsically motivated violence, the pleasure in inflicting pain, does not aim for a heightened sense of the self. Rather, it is linked to what happens to the 'other' - to the perpetrator's victim or inferior opponent. The fact that violence means pain and torment to those on whom it is inflicted is ineluctably tied to the corporal existence of a human being. At the same time, for the young offenders, the physical suffering of another person is often not only an unintended side-effect of violence, but the very thing they are striving for (see also Baumeister and Campbell, 1999). They take pleasure in the pain and injuries of their victims. The direct experience of their victim's vulnerability can exert such an attraction that the offenders cannot refrain from their beatings until the victim doubles over in pain. For instance, Kai compares himself to a 'pit bull' that must be 'whistled back' by others before he will stop pummeling his grievously injured opponent. If the victim's pain is the driving force behind a violent act, it presupposes a certain empathy with the victim on the part of the perpetrator, as was first observed by Georg Simmel (1900) and later emphasized by Hartmann Tyrell (1999). The latent process by which the perpetrator - who enjoys his victim's suffering - comes to identify with the victim can be seen in the passage of Kai's interview in which, alluding to a violent act by a friend, Kai says that, just once, when jumping on a person's head, he would like to 'hear it crack'. Asked by the interviewer what he means by this, Kai brings the victim into play, saying: 'It's brutal, absolutely brutal. If you do that to a person - it must be brutal for him.' When offenders like Kai are forced to admit to themselves that, while fully aware of their victim's vulnerability, they feel pleasure in his pain, their own behavior appears eerie to them. As a result, they occasionally pathologize themselves because they feel the need to exonerate themselves of guilt. One example can be seen in Kai's description of himself as having a 'perverse streak'. Kai does indeed have scruples, and at times he counters these by externalizing moral standards and delegating responsibility for his violent acts to the spectators who in most cases exist but fail to intervene. These 'neutralization techniques' (Sykes and Matza, 1957) allow the perpetrators to pursue their pleasure in others' pain; and in their narratives this pleasure is expressed by a symbolism of intoxication. It is only this motivational basis that can explain the extreme brutality and excessive violence that often mark the young offenders' attacks on victims who are physically inferior to them. 
This dimension of the violent experience comes to light in a story that Kai tells about an extremely cruel beating he gives a man in a Turkish fast food restaurant. In describing his victim, he at first says that he was an 'awful braggart', but later admits that the man simply had the bad luck of being 'at the wrong place at the wrong time'. Kai says that his cruel act gave him 'a nice feeling' that was based on 'inflicting pain'. Concluding his story, Kai once again offers an explanation for what he feels when he hits and torments his victims: 'For me it was awesome to see all the things you could do to a person.' Kay derives pleasure from making others the object of an experiment that takes them to their pain barrier. Furthermore, as in Kai's talk of a 'perverse streak', the attribute that he uses in German to describe this experiment - 'geil' - has a double meaning ('awesome/horny'), that sexualizes his cruelty.

Joe, a 17-year-old German youth who committed most of his violent crimes together with his Arab and Turkish friends, is also familiar with such motives, even though his crimes were less serious than those committed by Kai. Joe tells about an incident that centers on a Thai youth who borrows a video from Joe's Turkish friend Ural and then gives him back the wrong one. Joe and Ural accost the Thai in front of his apartment, a scuffle ensues, and finally Joe, joined by Ural, begins kicking the youth until his nose begins bleeding. He does not stop until the hallway is 'full of blood'. Up to a certain point, the progression of this situation can be grasped by the interactive dynamic derived from the need to resolve the conflict over the video cassette. However, the excessive use of force explodes the original scope of the two's intentions and their desire to put their opponent in his place. The following remark by Joe suggests why the conflict suddenly escalates the way it does: 'It's just so - gratifying. And you're glad he hurts. He keeps saying: "Stop, stop!", and you keep hitting him.' Here Joe links the positive experience of the violent act with his victim's cries of pain, which appear to incite him to additional blows, even though his opponent has admitted defeat and is begging for mercy. The extreme violence of this situation springs from the fact that the objective of Joe's behavior is his opponent's pain.

The third dimension of the intrinsic motive for violence - breaking with the everyday routine - results from the relationship between the violent situation and the offenders' normal lives, which are experienced as a great deal less intense. The appeal of violence lies in its capacity to produce an exceptional situation that radically differs from the youths' everyday existence. The young people relate that, in the act of violence, they experience moments of great intensity that are focused on the present and the immediacy of the action (see Buford, 1991; Katz, 1988). This exceptional state is created both by the tension that grips all their senses the moment they exercise violence, and by the fact that violence suspends, even scorns, the usual rules of human coexistence. Thus the desire to create this exceptional 
sensory state can be just as strong a motive for violence as the wish to produce an exceptional normative situation in which the offender deliberately violates the fundamental rules of civil interaction. In both cases, the spell cast on young people in violent moments renders all other motives secondary. In such moments, the reflective distance between the subject and his actions dissolves; the moment is reduced to pure speed and action. The youths lose sight of the possible ramifications of violence for themselves and the physical and mental consequences for their victims. As can often be observed, the offenders are so enthralled by the experience of violence that they act in contravention of their own moral feelings. They reach a state where they are unable to reflect on their action and even temporarily abandon self-control.

An episode from the life of 17-year-old Cruse, a Lebanese youth born in Berlin, illustrates this point. Cruse, who has been a member of various violent street gangs in the past and at the time of the interview regularly met with a group of young Arabs on the street, describes 'a nice fight', yes, 'the best fight of all', which occurred when he and several gang members returned from a swimming excursion. After they entered the subway car, two of his friends turned up their ghetto blaster, which led to a skirmish with 'four pretty big Germans' and ultimately to a tumultuous brawl that spilled out onto the platform in the next subway station, where several passers-by intervened. The enthusiasm with which Cruse recounts the incident shows the exhilarating dynamic of his violent action, which is not held in check as long as he is protected by his group. He leaves out no detail of his unrestrained violent behavior, describing, for instance, how he punches one man 'in the face and the nose', drawing both blood and tears, and how he butts his head into anther's 'Nazi nose' and 'kicks him again, again and again'. The phrases, which are meant to capture his feeling of euphoria, come thick and fast, culminating in the remark: 'Attacking at the same time, that's awesome, really awesome, that's better than any trip.' The attack on one of the four men in the subway, to which Cruse refers here, creates an ecstatic state that in his eyes is better than any drug-induced high. It is obvious that such violent experiences, which give the youths a taste of the extraordinary, will have an impact on them and motivate additional violence. The fascination of immorality and Dionysian excesses leads precisely to those acts that are often described as blind, as without reason and sense. ${ }^{12}$

\section{Mythologies of violence}

The repeated use of violence affects the self-image and normative ideals of the young offenders. If the experience of using force is appealing because 
it is linked to states of ecstasy and feelings of power, it will have permanent consequences for the youths' value systems. This has already been shown in the analysis of epiphanic experiences of violence which the young people regard as key to their new self-conception and as an authentic expression of their identities. The self-image that emerges from these epiphanic experiences takes on an everyday normality, and the young people make violence into a positive value. For them, posing a physical threat to others and being constantly willing to fight are ideals. They take steps to achieve these ideals and suffer if - due to a lack of courage or physical strength - they fail. They fight, train and suffer for their values.

Here 'values' is used in the strong sense of the word to mean moral ideas that have a motivating character and that, according to Emile Durkheim, are identified by the attribute of 'desirability' (Durkheim, 1953; Joas, 2000). If the concept of values is used here to analyze tendencies toward violent action, it is meant to convey the fact that the idealization of violence among young people not only represents one impulse among others, but is given a priority that allows the young people to assess their violence-inhibiting norms as subordinate or impermissible. This means that, in the name of 'strong evaluations' (Taylor, 1977), the youths abrogate the restrictive and imperative dimensions of the moral rules which Durkheim defined using the characteristics of 'duty' or 'obligation'. The practice of violence gains a mythic content as it is normatively charged.

As regards the young interviewees, there are two reasons one is justified in speaking of mythologies of violence. ${ }^{13}$ In the first place, the term captures the diverse ways they glorify power and strength. The young people expect violence to bring them a previously unknown recognition and to lend them an undreamt-of grandeur. The promise of 'an easy, quick, almost magical way of achieving power and prestige' - as Lewis Yablonsky (1962: 4) fittingly expresses it - prompts the young people to view violence as desirable. In the second place, the young people expect violence to have effects that in fact either do not materialize or come undone over the long term due to its negative consequences. Only the older interviewees are at times aware of the fact that the positive effects of violence last only for a short period of time and are in part chimerical. Its negative effects range from stigmatization in the youths' private lives to negative school or professional consequences and even to legal repercussions. It is in this sense that the glorious effects of violence are a mere myth.

The central expectation associated with mythologies of violence namely, that violence and victory in battle will bring recognition and a positive self-transformation - is typified by Murat. His idealized image of himself is closely linked to his ability to deliver blows without moral inhibition. He wants to be like the most brutal criminals he knows. His idols are the other members of his Turkish gang, some older, who are willing 
to commit acts of extreme violence. He explains: 'That's the way I'll be one day! Pow, no hesitation, really physical! If I keep on working out, my hands will get really strong ... And I want people to take notice of me first. I want them to talk about me, to say: "He's bad news, we don't want to pick a fight with him!' Well, one day I'll get them to respect me.' In order to achieve his idealized image as a fighter, Murat not only works out, but plans to undergo military training. Inspired by the Rambo films, he even expresses a desire 'to go to Vietnam'. Ignorant of the history of the Vietnam War, even believing it is still being fought, he explains that he's going to acquire 'street-fighting' skills in the bush and to learn how to 'fight fear'. Imagining himself in the role of a Vietnam fighter who risks his life to come to his friends' aid, Murat identifies the driving force behind these bold fantasies, the idea that his deeds will make him a decorated hero. 'Someday I really want to be No. 1, to be known or famous or something like that!' he says, adding: 'I don't want to be someone no one knows exists in the world.' He appears to know no middle ground between fame and obscurity. The glory in battle that excites his imagination is intended, in one fell swoop, to bridge the divide between the threat of being or remaining a nobody and the chance of being a winner. In his eyes, violence and fighting hold out the promise of being seen and recognized. The manner in which Murat mythologizes violence, which extends to an affectively charged, aggressive physicality, is inseparably linked to such expectations. He idealizes the image of a young man who has an aura of violence that strikes fear into others' hearts and forces them to respect him. A result of such idealizations is that the mere existence of a challenge, the mere question of who is stronger, creates a kind of compulsive need to respond with violence.

As is shown by Murat's explanations above, the groups to which the young people belong often supply role models and action arenas for their fighting ideals. The young people share with the group the same values and ideals. Hence, their immediate reality supports the mythologies of violence that make the youths believe that physical strength, fighting skills and violence will bring them recognition. Within the group, the youths try to gain recognition by demonstrating power and strength; outside the group, by violent acts that are intended to force their opponents or victims to express their respect. A phantasmagoric codification of violence plays a crucial role in this context. One example is the way the skinhead Kilian proudly identifies with the 'bad guys', the Nazis, who 'gassed six million Jews' and made the whole world quake in its boots. He overlays his violence with a symbolism that serves to rescue himself and his group from insignificance. For Kilian, the positive functions of identifying with evil, which the Nazis epitomize, lie in a wondrous enhancement of his self and his actions. However, the semantic gain which Kilian draws from both the National 
Socialist codification of violence and the fear of others always remains ambivalent, situated somewhere between phantasm and reality.

The grand effects that they hope to wring from violence run counter to the insight - had in lucid moments - that it is all just a fatal error. The youths' knowledge that they are not only feared but also hated by their victims joins the expanded sense of themselves that results from subjugating others and coercing them into obedience. The myth is robbed of its magic by the awareness that fear has nothing to do with respect and that recognition granted under duress is worth nothing at all (see also Straub, 1999). Hence, when answering the question of what it feels like when others are afraid of him, Kilian says:

It's a feeling of power, a feeling of pure power. You feel good, you think: you're the boss here and you can tell them to do anything you want, and they'll do it. Yes, that's how it is! A feeling of power! A thrill! You just feel good. Although, when you're at home or alone, sometimes you think about the consequences. And what you actually gain. I mean, the fact is, they actually think you're an asshole. That's the way it is! ... So, sometimes, in a quiet moment, you think: what good is it? Or you can't say what good it is. I don't know. The fact that they're afraid and only do what you say out of fear.

In this passage, Kilian clearly describes the ambiguity he feels toward the submissive behavior of others that is rooted in fear. His invigorating 'feeling of power' has a bitter aftertaste that comes from his awareness that he is in fact rejected by others. The gratification of violence comes with worrisome side effects, including, not least, Kilian's inability to distinguish between real respect and anticipatory obedience among his victims.

As the example of Kilian shows, this awareness may remain dormant for a long time because the youths do everything in their power to prevent others from making negative comments about them. Their fear of rejection forces them to latch onto practices that, even if they do not bring recognition, at least silence others. This vicious circle remains intact as long as the biographically acquired problem of recognition and self-respect is not resolved and a violent interpretive regime remains in effect. Up to this point, idealized, mythically charged images of violence endure - images that are responsible for making the fruits of violence, both perishable and regenerative, appear so desirable to the youth. However, with the insight that recognition cannot be acquired by force, this period of violence takes on the characteristics of a trajectory. The youths may quickly realize that the phases in which they wielded the greatest power are in fact times when they wasted opportunities and destroyed social relations. They are forced to realize that their action patterns do not make them immune to new forms of suffering. The young offenders remain marked by biographical paths that are paved with points of no return. 


\section{Acknowledgements}

I would like to express my thanks to the Institut für Sozialforschung in Frankfurt am Main for generously supporting the translation of this article from the German. It is a slightly modified version of Was ist eine 'Gewaltkarriere'?, originally published in Zeitschrift für Soziologie 33(4), 2004, pp. 266-84.

\section{Notes}

1 During the first interview, the initial questions concerned the different social contexts in which the young people lived at the time of the interview and in earlier phases of their lives. The three fields covered by these questions were: 1) school and work history, 2) family socialization, and 3) current recreational activities, friends and group affiliations. The next part of the interview sought to document the violent experiences the young people had had in the course of their lives. In this narratively structured section, each of the youths was asked to tell about the incidents in which they had come into contact with violence, either as observers, victims or perpetrators. On the one hand, the second interview encompassed specific questions on different thematic fields that extended beyond those in the first interview; on the other, it contained questions that addressed topics in the first interview from a different angle. With this combination of thematic repetition and variation, the interview not only explored new thematic fields relating to lifestyle, everyday perceptual patterns and normative attitudes, but also gathered more details of the youths' biographical experiences discussed in the first interview.

2 Measured against the statistic distribution of violent crimes among the sexes in the corresponding age group in Germany, there is a slight overrepresentation of female interviewees in the sample (see Pfeiffer and Wetzels, 1999). Nine youths were of German descent, and the other nine came from immigrant families: six were Turkish, two were of Arab descent, and one interviewee came from Poland but was a member of a Turkish gang. Four of the interviewees were in the skinhead scene, and five were members of a violent Turkish or Arab gang. The others were on the fringes of the above-mentioned groups, had been members of such groups for a short time, had shifted between different groups, or had never been members of a violent group. Contact with the young people was arranged by a Berlin secondary school and by several facilities that had been charged by a juvenile court with carrying out 'educational measures' under Section 10 of Germany's Jugendgerichtsgesetz - the penal code for young offenders.

3 It must be noted, though, that individual authors in the symbolic interactionist tradition define 'trajectory' differently than Strauss and Glaser or 
Schütze. For example, in the work of Andrew Abbott (2001), trajectory refers to a consistent sequence of events within the framework of a master narrative. It enables individuals to cognitively structure all the incidents in a specific phase of their lives as part of a single developmental process. According to Abbot, a trajectory is simply a series of events that, in a biographical narrative, is based on a specific progression and action pattern which is for the most part institutionally defined. The conceptual counterpart to the trajectory in Abbott's work is the turning point, defined as a pivotal point in biographical narratives that marks the transition from one trajectory to another, such as the shift from the 'school' to the 'occupational' trajectory. Thus, Abbot's use of 'trajectories' is closer to Schütze's concept of Handlungsschemata (action patterns) than it is to Schütz's concept of a Verlaufskurve des Erleidens (trajectory of suffering).

4 It is by no means the case that physical abuse in families inevitably leads to violence in adolescence and young adulthood, yet there is overwhelming empirical evidence of the opposite: a significantly large percentage of adolescents and young adults who physically abuse others have themselves been victims of family violence (see Lewis et al., 1989).

5 Nevertheless, this is a second-order construct (Schütz, 1953) that does more than just duplicate the young people's stories. In the interview, some of the youths even explicitly denied any link between family socialization and their subsequent affiliation with a violent group. This was the only way they could present their lives as a product of their own free will as opposed to being a consequence of inevitable developments. Despite such arguments, the family-related narratives of the same youths were always permeated by an interpretative pattern that allowed them to see themselves as the powerless victims of family violence. At times the narrative and interpretive passages of the interview contradict each other, with the result that the self-interpretation of the individuals does not always follow a consistent 'causal attribution' (Nollmann, 2003: 126 ff.). Nor is it always entirely congruent with the trajectory of suffering portrayed here, which at a later point in life turns into violent action. If an interpretative pattern reveals itself in narratives but is argued against by the narrator, its force is all the more apparent - and it can be cleared of the suspicion of any justificatory intent. In such cases, it is up to the sociologist to diagnose a phase of passive victim status. This is particularly true of its connection to a later phase involving an active, violent re-appropriation of the power to act, especially since the young people themselves rarely see this connection. It is only revealed by a sociological analysis of the semantics incorporated into the young people's patterns of biographical depiction.

6 See Sutterlüty (2002: $147 \mathrm{ff}$.) regarding the distinctions made in this passage between 'experiences of powerlessness' and 'experiences of disrespect', and between the 'need for recognition' and the 'claim to recognition'. 
7 Experiences of this type can also be observed among young people with violent careers. They represent epiphanic experiences that have no direct connection with the previous history of suffering violence in the family. Such 'major epiphanies' are based on violent acts that result from contingent, situational conditions and usher in a new stage of violence by bringing the perpetrator into a previously unknown context of violence and by permanently tearing down his moral inhibitions. This was the case with 18-year-old Sven, whose violent career was propelled forward when, at age 15, he and two friends chased down two Vietnamese cigarette dealers, beat them brutally, and finally tore the goods out of the hands of the screaming men. Sven said he experienced an 'adrenaline rush' and 'broke through his inhibitions'. He also explained how, after this 'first time', he joined the violent 'escapades' of his friends since he wanted to relive this intoxicating experience of superior power in entirely different contexts. In several instances, the victims of his violence were what he called Glatzköppe, or skins. The effect of violence on 16-year-old Jacques, who is of Turkish descent, was the exact opposite. He was involved in a fight between immigrant youths and a group of skinheads that culminated in extreme violence, but although he regarded the fight - in which Murat (see later) also participated - as a 'major epiphany', it was one that horrified him and made him turn his back on violence. Interestingly enough, Jacques grew up in a family marked by positive interpersonal relations. His stories about his family contain no references to violence or shows of disrespect.

8 This reference to conversion narratives is meant to provide insight into the cultural historical origins of the interpretative patterns that inform the depiction of violent experiences as biographical turning points. In addition to offering the evolutionary thesis that the model for such depictions stems from religious contexts, the reference is meant to call attention to a homology: Bernd Ulmer (1988) has discussed the three-stage temporal structure of conversion narratives, which always contain the 'temporal marker' of a conversation experience as well as a pre-conversion and a post-conversion biography. This structure can also be found in biographical narratives of violent youths. The comparison between conversion narratives and stories in which individual violent acts function as biographical turning points is based on this structural analogy. By no means does it mean to imply that the epiphanic experiences of violence that are interpreted as turning points are religious or quasi-religious experiences like moments of conversion.

9 Her mother also largely supports the family order. Contrary to Bebek's expectations, her mother does not stick up for her rights or even recognize the injustice done to her. This is an important detail, as can be seen by a comparable case from the interview material. Seventeen-year-old Janet, one 
of seven children in an Arab family, was beaten by her father for the same reasons that Bebek's father beat her - once when he noticed her talking to a boy on the phone. From the start, though, the family formed a broad alliance against her abusive father. He was despised by all and largely excluded from communication processes within the family. Here the violent perpetrator is marginalized, and his victim enjoys the solidarity and protection of the other family members. Significantly enough, Janet did not experience powerlessness in the same way as Bebek, who did not have an intercessor or guardian within the family but was always at the mercy of her violent father and brother. It is certainly no coincidence that, in contrast to Bebek, Janet did not develop a violent career.

10 This earned her the reputation of being a 'fighting lady'. Bebek rejected the label, not because it did not apply to her, but because she did not want others to hold her to this image in situations where she wanted to play a different role - at a festive wedding, for instance. The image of a violent girl capable of defending herself did not wholly take possession of her in all situations, mainly because it conflicted with her gender identity - a conflict that could probably not arise among male youths (see Bruhns and Wittmann, 2001). Joachim Kersten (1997) has pointed out that, in our cultures, violent actions by young men are regarded as a fulfillment of their masculinity, even if they are not always considered legitimate or are at times demonized. Women, by contrast, have no cultural pattern at their disposal to interpret violent action as a fulfillment of femininity. Rather, violence brings women into conflict with gender-specific cultural expectations. This cultural restriction is probably the reason that, even if young women are beaten and treated with disrespect in the family, they turn to violent action much less frequently than their male peers.

11 The line of research dealing with the 'cycle of violence' has repeatedly demonstrated a statistical link between violence in the family and violent crime in adolescence and young adulthood, but it has not been able to account for the mechanism by which violence is transferred from one area of life to the other; see Jaffe et al. (1990), as well as Sutterlüty (2002).

12 For clarification: even if intrinsic motives for violence bring to violent careers a strongly physical dimension that cannot be explained in its entirety solely by the young offenders' family history as victims, such motives remain embedded in biographical processes. The young people with developmental stories as described above have had diverse opportunities to come into contact with the experiences that lead to intrinsic motives for violence. Furthermore, the only youths who are able to integrate the euphoria of using violence into their self-image are victimized individuals with a biographically acquired disposition to violence. As is shown by a comparison with the three interviewees without violent careers, 
other youths immediately reverse course when they start discovering similar sides to themselves. This is why the thesis of the existence of intrinsic motives for violence has little to do with the theories of violence proposed by Elias Canetti (1962) and Wolfgang Sofsky (1996), who regard the pleasure in violence as an anthropological constant and deny the explanatory power of biographical factors (for a detailed discussion, see Sutterlüty, 2002).

13 Hans Joas (2003) uses the concept of a mythology of violence to characterize efforts to positively re-evaluate violence in wars between states and in struggles within society. He particularly stresses the 'myth of regeneration through violence'.

\section{References}

Abbott, A. (2001) 'On the Concept of Turning Point', in Time Matters: On Theory and Method, pp. 240-60. Chicago, IL: University of Chicago Press. Alfaro, J.D. (1981) 'Report on the Relationship Between Child Abuse and Neglect and Later Socially Deviant Behavior', in R.J. Hunner and Y.E. Walker (eds) Exploring the Relationship Between Child Abuse and Delinquency, pp. 175-219. Montclair, NJ: Allanheld, Osmun \& Co.

Alheit, P. and B. Dausien (1992) 'Biographie - ein "modernes Deutungsmuster"? Sozialstrukturelle Brechungen einer Wissensform der Moderne', in M. Meuser and R. Sackmann (eds) Analyse sozialer Deutungsmuster. Beiträge zur empirischen Wissenssoziologie, pp. 161-82. Pfaffenweiler: Centaurus.

Baumeister, R.F. and W.K. Campbell (1999) 'The Intrinsic Appeal of Evil: Sadism, Sensational Thrills, and Threatened Egotism', Personality and Social Psychology Review 3(3): 210-21.

Becker, H.S. (1963) Outsiders: Studies in the Sociology of Deviance. New York: Free Press.

Birkbeck, C. and G. LaFree (1993) 'The Situational Analysis of Crime and Deviance', Annual Review of Sociology 19: 113-37.

Blumer, H. (1969) 'The Methodological Position of Symbolic Interactionism', in Symbolic Interactionism. Perspective and Method, pp. 1-60. Englewood Cliffs, NJ: Prentice-Hall.

Bruhns, K. and S. Wittmann (2001) "Wir sind doch keine Schwacheier" Mädchen in gewaltbereiten Jugendgruppen', Journal für Konflikt- und Gewaltforschung 3(2): 45-63.

Buford, B. (1991) Among the Thugs. London: Secker \& Warburg.

Canetti, E. (1962) Crowds and Power. London: Gollancz.

Denzin, N.K. (1989) Interpretive Biography. Newbury Park, CA: Sage.

Durkheim, E. (1953) 'The Determination of Moral Facts', in Sociology and Philosophy, pp. 35-63. London: Cohen \& West. 
Engfer, A. (1986) Kindesmißhandlung. Ursachen - Auswirkungen - Hilfen. Stuttgart: Enke.

Glaser, B.G. and A.L. Strauss (1967) The Discovery of Grounded Theory. Strategies for Qualitative Research. New York: Aldine de Gruyter.

Honneth, A. (1996) The Struggle for Recognition. The Moral Grammar of Social Conflicts. Cambridge, MA: MIT Press.

Hughes, E.C. (1971) 'Cycles, Turning Points, and Careers', in The Sociological Eye: Selected Papers, pp. 124-31. Chicago, IL: Aldine-Atherton.

Jaffe, P.G., D.A. Wolfe and S.K. Wilson (1990) Children of Battered Women. Newbury Park, CA: Sage.

Joas, H. (2000) The Genesis of Values. Chicago, IL: University of Chicago Press. Joas, H. (2003) 'The Dream of a Modernity without Violence', in War and Modernity: Studies in the History of Violence in the 20th Century, pp. 29-42. Cambridge: Polity Press.

Katz, J. (1988) Seductions of Crime: Moral and Sensual Attractions in Doing Evil. New York: Basic Books.

Kersten, J. (1997) 'Risiken und Nebenwirkungen: Gewaltorientierung und die Bewerkstelligung von "Männlichkeit" und "Weiblichkeit" bei Jugendlichen der underclass', in S. Krasmann and S. Scheerer (eds) Die Gewalt in der Kriminologie. Kriminologisches Journal, Beiheft 6, pp. 103-14. Weinheim: Juventa.

Lemert, E.M. (1967) 'The Concept of Secondary Deviation', in Human Deviance, Social Problems, and Social Control, pp. 40-64. Englewood Cliffs, NJ: Prentice-Hall.

Lewis, D.O., C. Mallouh and V. Webb (1989) 'Child Abuse, Delinquency, and Violent Criminality', in D. Cicchetti and V. Carlson (eds) Child Maltreatment: Theory and Research on the Causes and Consequences of Child Abuse and Neglect, pp. 707-21. Cambridge: Cambridge University Press.

Matza, D. (1964) Delinquency and Drift. New York: Wiley.

Merton, R.K. (1949) 'The Self-Fulfilling Prophecy', in Social Theory and Social Structure: Toward the Codification of Theory and Research, pp. 179-95. Glencoe, IL: Free Press.

Nollmann, G. (2003) 'Warum fällt der Apfel nicht weit vom Stamm? Die Messung subjektiver intergenerationaler Mobilität', Zeitschrift für Soziologie 32(2): 123-38.

Osofsky, J.D. (1995) 'The Effects of Exposure to Violence on Young Children', American Psychologist 50(9): 782-8.

Pfeiffer, C. and P. Wetzels (1999) 'Zur Struktur und Entwicklung der Jugendgewalt in Deutschland. Ein Thesenpapier auf Basis aktueller Forschungsbefunde', Aus Politik und Zeitgeschichte B 26: 3-22.

Schütz, A. (1953) 'Common-Sense and Scientific Interpretation of Human Action', Philosophy and Phenomenological Research 14(1): 1-37.

Schütze, F. (1995) 'Verlaufskurven des Erleidens als Forschungsgegenstand der 
interpretativen Soziologie', in H.-H. Krüger and W. Marotzki (eds) Erziehungswissenschaftliche Biographieforschung, pp. 116-57. Opladen: Leske + Budrich.

Simmel, G. (1900) 'Zu einer Theorie des Pessimismus', Die Zeit. Wiener Wochenschrift für Politik, Volkswirtschaft, Wissenschaft und Kunst 22(277): 38-40.

Sofsky, W. (1996) Traktat über die Gewalt. Frankfurt am Main: Fischer.

Straub, J. (1999) 'Mensch zu sein will Anerkennung. Tzvetan Todorovs anthropologischer Versuch über die conditio humana', Handlung, Kultur, Interpretation 8(1): 92-108.

Strauss, A.L. (1993) Continual Permutations of Action. New York: Aldine de Gruyter.

Strauss, A.L. and J. Corbin (1990) Basics of Qualitative Research: Grounded Theory Procedures and Techniques. Newbury Park, CA: Sage.

Strauss, A.L. and B.G. Glaser (1970) Anguish: A Case History of a Dying Trajectory. San Francisco, CA: Sociology Press.

Sutterlüty, F. (2002) Gewaltkarrieren. Jugendliche im Kreislaufvon Gewalt und Missachtung. Frankfurt am Main: Campus.

Sutterlüty, F. (2004) 'Ist Gewalt rational?', WestEnd. Neue Zeitschrift für Sozialforschung 1(1): 101-15.

Sykes, G.M. and D. Matza (1957) 'Techniques of Neutralization: A Theory of Delinquency', American Sociological Review 22(6): 664-70.

Taylor, C. (1977) 'What Is Human Agency?', in T. Mischel (ed.) The Self: Psychological and Philosophical Issues, pp. 103-35. Oxford: Blackwell.

Thomas, W.I. and D.S. Thomas (1928) The Child in America: Behavior Problems and Programs. New York: Knopf.

Todorov, T. (2001) Life in Common: An Essay in General Anthropology. Lincoln: University of Nebraska Press.

Tyrell, H. (1999) 'Physische Gewalt, gewaltsamer Konflikt und "der Staat" Überlegungen zu neuerer Literatur', Berliner Journal für Soziologie 9(2): 269-88.

Ulmer, B. (1988) 'Konversionserzählungen als rekonstruktive Gattung. Erzählerische Mittel und Strategien bei der Rekonstruktion eines Bekehrungserlebnisses', Zeitschrift für Soziologie 17(1): 19-33.

Winnicott, D.W. (1956) 'The Antisocial Tendency', in Collected Papers: Through Paediatrics to Psycho-Analysis, pp. 306-15. London: Routledge.

Yablonsky, L. (1962) The Violent Gang. New York: Macmillan.

- FERDINAND SUTTERLÜTY is a research fellow at the Institut für Sozialforschung in Frankfurt am Main. He is the author of Gewaltkarrieren: Jugendliche im Kreislauf von Gewalt und Missachtung (Campus Verlag, 2002; Dissertationspreis awarded by the Deutsche Gesellschaft für Soziologie). His research areas are 
mainly focused on the sociology of violence and crime, symbolic orders of social inequality and ethnic relations, the sociology of religion, social theory, interpretive paradigms and qualitative methods, including ethnography. Available in English are his articles 'The Belief in Ethnic Kinship: A Deep Symbolic Dimension of Social Inequality', Ethnography 7(2), 2006, pp. 179-207 and 'Bashing the Migrant Climbers: Interethnic Classification Struggles in German City Neighborhoods', International Journal of Urban and Regional Research 30(4), 2006, pp. 798-815 (with Sighard Neckel). Address: Institut für Sozialforschung, Senckenberganlage 26, 60325 Frankfurt am Main, Germany.

[email: Sutterluety@em.uni-frankfurt.de] 